\title{
Structural Characterization and Residual Stress of Plasma Nitrided AISI 4340 Steel.
}

\author{
Mohammad Bafandegan ${ }^{1 *}$, AyhanÇelik ${ }^{2}$ \\ ${ }^{1,2}$ Department of Mechanical Engineering, University of Atatürk, P.C. 25030, Erzurum, Turkey. \\ E-mail: m.bafandegan@atauni.edu.tr
}

\begin{abstract}
In this work,AISI 4340 steel samples were plasma nitrided in a mixture of $50 \% \mathrm{~N}_{2}-50 \% \mathrm{H}_{2}$ process gas at $470^{\circ} \mathrm{C}$ temperatures for different nitriding times of 1,4 and $8 \mathrm{~h}$. Prior to nitriding, the specimens were normalized at $850^{\circ} \mathrm{C}$ for $30 \mathrm{~min}$. Nitrided samples were characterized using optical microscopy (OM), scanning electron microscopy (SEM), X-Ray diffraction (XRD) and microhardness testing. The thickness of diffusion and compound layers was determined by using cross-sectional OM \& SEM micrographs and microhardness profiles. Residual stresses in diffusion layers were determined using XRD g- $\sin ^{2} \psi$ method. The results showed that compound layers of 4.5-7 $\mu \mathrm{m}$ thick consisting of $\mathrm{Fe}_{4} \mathrm{~N}(\gamma)$ and $\mathrm{Fe}_{2-3} \mathrm{~N}(\varepsilon)$ phases are formed on samples surface. The thickness of the diffusion layer increases from $90 \mu \mathrm{m}$ to $240 \mu \mathrm{m}$ with increasing plasma nitriding time. The surface and cross-sectional hardness are also increased with increasing nitriding time and the maximum surface hardness of $750 \mathrm{HV}$ obtained after $8 \mathrm{~h}$ plasma nitriding. All samples contain compressive residual stress and the highest compressive residual stress of $260 \mathrm{MPa}$ is obtained for sample nitrided.
\end{abstract}

Keywords: Plasma Nitriding, AISI 4340 steel, Microstructures, Hardness, Residual Stress

\section{Introduction}

In spite of appearance modern materials, the steels are still used in most applications. AISI 4340 nickelchromium-molybdenum alloy steel is a kind of high strength low alloy steel with deep hardenability. By proper heat treatment a combination of high ductility, high toughness and high tensile, fatigue and creep strengths could be obtained. This steel is widely available as billet, bar, rod, forgings, sheet, tubing, and welding wire.Typical applications include bolts, screws, and other fasteners; gears, pinions, shafts, and similar machinery components; crankshafts and piston rods for engines; and landing gear and other critical structural members for aircraft[1].

In some applications, the steel should have a good combination of strength and toughness therefore it should be used in normalized or quenched and tempered at $650^{\circ} \mathrm{Ctemperatures.} \mathrm{When} \mathrm{it} \mathrm{is} \mathrm{used} \mathrm{in} \mathrm{normalized} \mathrm{provides} \mathrm{a}$ good combination of strength and toughness required for high fatigue strength and severe service conditionsuch as crankshaft applications[2].

However, in such application component surface hardness becomes controlling parameter for wear resistance and fatigue strength. Various surface engineering techniques such as carburizing, nitriding and nitrocarburizing have been applied successfully to improve surface hardness of this alloy [3,4]. Plasma nitriding effectively enhances surface strength through introduction of nitrogen into the steel surface via solid state diffusion in low and moderate temperatures[5-7].

As a result, two different structures occur in the ion nitriding process. The compound layer (white layer), which is very thin and consists of iron nitrides $\left(\varepsilon-\mathrm{Fe}_{3} \mathrm{~N}, \gamma^{\prime}-\mathrm{Fe}_{4} \mathrm{~N}\right)$, is not attacked by nital, so it is referred to as the compound layer. The layer is hard and fracturable. Beneath the layer is the so-called diffusion zone, where the nitrogen has mainly been incorporated into the existing iron lattice as interstitial atoms or as a finely dispersed alloy precipitate $[8,9]$. Nitrogen may also form stable nitrides with nitride-forming elements such as $\mathrm{Mo}, \mathrm{Cr}$, and $\mathrm{Si}$, constituting the diffusion zone [10].

Y. Sun and T. Bel have developed a mathematical model to simulate the plasma nitriding process of low alloy steel. also simple models have been developed to describe the influence of such properties as depth and strength of the nitride case on the mechanical specification of the nitride steel. Results and discussion showed that the model can predict the distribution of nitrogen in solution and in the form of alloy nitride precipitates and the iron nitride layer thickness developed during plasma niriding. Also it is shown that surface modification of low alloy steel via plasma nitriding, improves the mechanical properties[11].A. Celik and S. Karadeniz have studied structure of nitriding layers and fatigue limit of AISI4140 steel. They reported that plasma nitriding improves the fatigue strength by up to $35 \%$ and Quenched specimens have a higher surface hardness than normalized specimens after the ion nitriding process[12, 13].AkgunAlsaran, AyhanCelik and their colleagues have Structural and mechanical characterized of ion-nitrided AISI 5140. The optimum condition of plasma nitrided and mechanical properties of ion-nitrided AISI 5140 low-alloy steelwere determined. They have reported that the compound layer thickness and the case depth increase with increasing treatment time and temperature. The most effective parameter on surface hardness, compound layer, diffusion layer and fatigue limit was founded[5, 
$8,14,15]$. A. Akbari and his colleagues have reported the effect of initial microstructure on plasma nitriding and wear behavior of AISI M2 steel. They have shown that plasma nitriding increased the surface hardness of sample by $330 \%[6,16]$. Ali $\mathrm{H}$. Asharan and Qian Zou have studied, the tribological and Metallurgical Properties of plasma and gas methods of Nitrided AISI 4340 Steel. The best results were founded in plasma nitride methodCompared withgas nitride [17]. Temper temperature was the parameter that varied in J. L. R. Muzart and R. Binder studies. They have showed that the microhardness of the AISI 4340 plasma nitrided layer is very dependent on the structure of the material before the treatment process [18].

Most of the research on the plasma nitriding of AISI 4340 steel have been performed on quenched and temper state $[5,17-25]$ and to our knowledge there is no study about AISI 4340 plasma nitriding without Q\&T initial heat treatment. In this study, AISI 4340 low alloy steel was plasma nitrided under different conditions. Prior to nitriding the specimens were normarized. The process variables are investigated including time $(1,4$ and $8 \mathrm{~h})$ at $470^{\circ} \mathrm{C}$ temperature under a constant gas mixture ratio $50 / 50$ of N2 and $\mathrm{H} 2$ and pressure of $5 \mathrm{mbar}$.

\section{Experimental details}

Specimens were prepared from commercial Cr-Mo-Ni low alloy AISI 4340 steel, with chemical composition (Wt. \%) given Table 1; which was obtained via optical emission spectrometry analysis using an SPECTRO M8Germany analyzer.Specimens with dimensions of $15 \mathrm{~mm}$ height and $8 \mathrm{~mm}$ in diameter were machined from extruded round bar and were subjected to normalizing heat treatment by austenitizingat $850^{\circ} \mathrm{C}$ for $30 \mathrm{~min}$ followed by air cooling. The specimens after normalizing had $280 \pm 10 \mathrm{HV}$ hardness. Surface of the specimens were ground and polished with a $1 \mathrm{~mm}$ diamond suspension to a surface roughness $\left(\mathrm{R}_{\mathrm{a}}\right)$ of $0.4 \mu \mathrm{m}$.

Table 1. Chemical composition of AISI 4340 steel.

\begin{tabular}{lllllllllll}
\hline $\mathrm{C}$ & $\mathrm{Cr}$ & $\mathrm{Ni}$ & $\mathrm{Mo}$ & $\mathrm{Mn}$ & $\mathrm{Si}$ & $\mathrm{S}$ & $\mathrm{P}$ & $\mathrm{Al}$ & $\mathrm{Cu}$ & $\mathrm{Fe}$ \\
\hline 0.373 & 1.570 & 1.700 & 0.219 & 0.660 & 0.243 & 0.007 & 0.014 & 0.012 & 0.067 & Bal. \\
\hline
\end{tabular}

A schematic diagram of the ion nitriding system is show in Fig. 1. It consists of a stainless steel chamber with glass window in which an insulated central electrode is situated, potential surround this. The cathode has a nest on which the specimen is located and the specimen base was made of low alloy steel. A thermocouple is connected to the specimen thorough the cathode to monitor the specimens temperature. Prior to nitriding the reactor was pumped down to a base pressure of 0.03 mbar. Nitriding was carried out using a DC pulsed supply unit for plasma generation, with precise adjustment of discharge current, pulse frequency and duty cycle. An auxiliary heating system affords full control over the sample temperature, which was measured by means of a $\mathrm{K}$ type Ni- Cr-Ni thermocouple directly fastened on the specimen's base $[8,12]$. The constant process parameter were: gas mixture $50 \% \mathrm{~N} 2-50 \% \mathrm{H} 2$ and work pressure 5 mbar. Before the specimens were placed into the plasma chamber the specimens were cleaned with alcohol. Prior to nitriding process, a sputter cleaning process was carried out using hydrogen gas for $20 \mathrm{~min}$. at $480 \mathrm{~V}$ to remove the passive layers on the surface. During sputtering a small amount of material is removed from the surface. To prevent oxidation, after nitriding, the specimens were allowed to cool in the vacuum chamber to reach less than $250^{\circ} \mathrm{C}$. The tolerance of measured parameter were: $\pm 5^{\circ} \mathrm{Cin}$ temperature, \pm 3 minute in time and $\pm 0.2 \mathrm{mbar}$ in pressure. Fig. 2 shows the specimens in the plasma chamber during nitriding process

After plasma nitriding, the samples were carefully cross-sectioned and embedded in acrylic resin and then polished with a series of emery papers from coarse to fine type followed by cloth polishing with an application of 1 to $3 \mu \mathrm{m}$ diamond suspensions to obtain a mirror finish for metallographic studies and they were etched with nitalragent (3.5 percent nitricacid in ethanol) to be observed by ESEM, FEI QUANTA- FEG250 scanning electron microscopy and Olympus PMG3 optical microscope.

The phase composition of un-nitrided and plasma nitride specimens and residual stress created on samples surface were examined by a GNR X-ray diffractometer using a Co $\mathrm{K}_{\alpha}$ radiation $(\lambda=0.17890 \mathrm{~nm})$ operated at 30 $\mathrm{KV}$ and $30 \mathrm{~mA}$ within a $2 \theta$ range from $20^{\circ}$ to $110^{\circ}$. Surface hardness measurements were performed for each sample by using a SHIMADZU microhardness testing equipment using Vickers indenter under a load of $50 \mathrm{~g}$ and loading time of $10 \mathrm{~s}$.

\section{Results and discussions}

Typical optical microscopy images of the normalized sampleconsists of upper bainite and pearlite that was prepared by optical microscopy showed in Fig. 3.The SEM and metallographic examination show that nitrided layer consists of two layers as displayed in fig. 4. A compound layer was formed on the top surface. Increasing the plasma nitriding time from $1 \mathrm{~h}$ to $8 \mathrm{~h}$ results in a increase of compound layer thickness from 4.5 to $7 \mu \mathrm{m}$ and thehighest compound layer thicknessobtained at $470^{\circ} \mathrm{C}$, 8 h.Fig. 5 depicts cross-sectional optical microscopy images of samples plasma nitridedat $470^{\circ} \mathrm{C}, 8 \mathrm{~h}$. Nitrided layers are composed of a thin compound (white) and wide diffusion layers. The compound layers are not readily seen in optical microscopy images as they are brittle easily damaged at the specimen edges. To better visualize the white layers SEM images were prepared. From the OM and SEM cross-sectional images thickness of the compound and diffusion layers were determined 
quantitatively and their variations are depicted in table. 2. The diffusion layer thickness increased with increasing nitridingtime.

Same as results of the present research, For AISI 4340 steel it was reported thatthe compound layer thickness and diffusion layer thickness increase with increasing plasma nitriding time[20].

XRD patterns of the selected samplesinclude un-nitrided and nitrided for $1 \mathrm{~h}$ at $470^{\circ} \mathrm{C}$ temperatures are shown in Fig. 6. For samples nitrided at $470^{\circ} \mathrm{C}$ XRD pattern reveals existence of $\gamma-\mathrm{Fe}_{4} \mathrm{~N}$ and $\varepsilon-\mathrm{Fe}_{2-3} \mathrm{~N}$ phases in compound layer.It was obvious that with increasing time at the same temperature, the intensity of $\varepsilon$ nitrided phase decreases.There is also a diffraction pick of molybdenum and chromium nitride at due to the presence of molybdenum and chromium in the base material.The development of $\gamma$ or $\varepsilon$ compound layer can be related to both iron population and sputtering phenomenon during nitriding.

Vickers indents on plasma nitrided AISI 4340 steel at $470^{\circ} \mathrm{C}$ and $4 \mathrm{~h}$ is shown in Fig. 7. Cross-section microhardness profile of the samples nitride at $470^{\circ} \mathrm{C}$ and different time are shown in Fig.8. The hardness profile of each specimen was determined by three measurements at the cross section and average was selected. The microhardness profiles indicate that the hardness of nitrided specimens decrease from the surface to core, due to the concentration of metal nitrides decreases towards the core. The compound layer and diffusion layer are considered as hardened case after nitriding. By increasing of the plasma nitriding time, due to diffusion of more nitrogen atoms, the nitriding layer gets thicker.

The total case depth was measured based on the depth below the surface at which microhardness is $50 \mathrm{HV}$ units higher than that of the core in accordance with ASTM E 384 [17]. With increasing nitriding time the diffusion layer thickness was increased.The lowest diffusion layer thickness was obtained $90 \mu \mathrm{m}$ at $470^{\circ} \mathrm{C}, 1 \mathrm{~h}$ and the highest thickness was obtained $240 \mu \mathrm{m}$ at $470^{\circ} \mathrm{C}, 8 \mathrm{~h}$.

Table 2. Structure analyze of AISI 4340 steel, plasma nitrided at different conditions.

\begin{tabular}{ccccccc}
\hline cod & $\begin{array}{c}\text { Temperature } \\
\left({ }^{\circ} \mathbf{C}\right)\end{array}$ & $\begin{array}{c}\text { Time } \\
(\mathbf{h})\end{array}$ & $\begin{array}{c}\text { Surface hardness } \\
(\mathbf{H V})\end{array}$ & $\begin{array}{c}\text { Compound } \\
\text { la. } \mathbf{T h} .(\boldsymbol{\mu m})\end{array}$ & $\begin{array}{c}\text { Diffusion la. } \\
\text { Th. }(\boldsymbol{\mu m})\end{array}$ & $\begin{array}{c}\text { Residual } \\
\text { Stress }(\mathbf{M p a})\end{array}$ \\
\hline 0 & Un-nitrided & - & 280 & - & - & - \\
\hline 1 & 470 & 1 & 600 & 4.5 & 90 & 240 \\
\hline 2 & 470 & 4 & 680 & 5.5 & 170 & 255 \\
\hline 3 & 470 & 8 & 750 & 7 & 240 & 260 \\
\hline
\end{tabular}

The surface hardness, compound layer thickness, case depth and surface compressive residual stress of ionnitridedmaterial depending on the process parameters are given in table 2. Results shows that thesurface hardness of specimens increase with increasing plasma nitriding time. At the temperature $470^{\circ} \mathrm{C}$ and time $1 \mathrm{~h}$, the lowest values of surface microhardness were obtained $600 \mathrm{HV}$ and the highest surface hardness was achieved $750 \mathrm{HV}$ at the $470^{\circ} \mathrm{C}$ and 8 hours. A residual compressive stress has been detected in all cases on the sample surfaceand highest compressive residual stress was obtained $260 \mathrm{Mpa}$ at 8 hours plasma nitrided time. Also the compound layer thickness and case depth increases with increasing time.

\section{Conclusion}

From the present study of the structural characterization of AISI 4340 steel plasma nitrided, the followings are resulted:

- Compound layer consisting of $\mathrm{Fe}_{4} \mathrm{~N}(\gamma)$ and $\mathrm{Fe}_{2-3} \mathrm{~N}(\varepsilon)$ phases are formed on samples surface and the highest compound layer thickness was obtained $7 \mu \mathrm{m}$ at $470^{\circ} \mathrm{C}, 8 \mathrm{~h}$.

- With increasing time at the $470^{\circ} \mathrm{C}$ temperature, the intensity of $\mathrm{Fe}_{2-3} \mathrm{~N}(\varepsilon)$ nitrided phasewas decreased.

- The diffusion layer thickness was increased with increasing treatment time and the thickest diffusion layer was obtained $240 \mu$ mat $470^{\circ} \mathrm{C}, 8 \mathrm{~h}$.

- The surface hardness was increased with increasing treatment time andthe highest surface hardness was found $750 \mathrm{HV}$ at $470^{\circ} \mathrm{C}, 8 \mathrm{~h}$.

- The compressive residual stress wasincreased with increasing nitriding time and the highest compressive residual stress of $260 \mathrm{MPa}$ was obtained at $8 \mathrm{~h}$ nitriding time.

\section{References}

[1] GarrisonJr W M 1990 Ultrahigh-strength steels for aerospace applications JOM42 20-4

[2] Arul Mozhi Varman J P and Balasubramanian M 2013 Wear analysis of D.C. pulsed plasma nitriding of AISI 4340 low alloy steel for crankshaft application. In: TMS Annual Meeting Supplemental Proceedings: Metals \& Materials Society) pp 209-15

[3] Funatani K 2004 Heat treatment of automotive components: Current status and future trends Transactions of the Indian Institute of Metals57 381-96

[4] Bruhl S P, Cabo A, Tuckart W and Prieto G 2016 Tribological behaviour of nitrided and nitrocarburized carbon steel used to produce engine parts Ind. Lubr. Tribol.68 125-33

[5] Lawall I T, Muzart J L, Kuhnarroyo I and Desouza A R 1993 Macroscopic characterics of plasma- nitrided AISI-4340 steel J. Mater. Sci.28 5036-9 
[6] Akbari A, Mohammadzadeh R, Templier C and Riviere J P 2010 Effect of the initial microstructure on the plasma nitriding behavior of AISI M2 high speed steel Surface \& Coatings Technology204 4114-20

[7] Sharma Y C, Kumar R, Vidyasagar V and Bhardwaj D 2018 Low temperature plasma ion nitriding (PIN) of Inconel 690 alloy Materials Research Express6 026559

[8] Alsaran A and Celik A 2001 Structural characterization of ion-nitrided AISI 5140 low-alloy steel Materials Characterization47 207-13

[9] Scheuer C J, Zanetti F I, Cardoso R P and Brunatto S F 2018 Ultra-low_to high-temperature plasma-assisted nitriding: revisiting and going further on the martensitic stainless steel treatment Materials Research Express6 026529

[10] Jebaraj J J M, Morrison D J, McLaughlin J B and Suni I I 2014 Effect of Nitriding on the Hydrogen Diffusion Coefficient through AISI 4340 J. Electrochem. Soc.161 C261-C7

[11] Bell T, Sun Y and Suhadi A 2000 Environmental and technical aspects of plasma nitrocarburising Vacuum 59 14-23

[12] Celik A and Karadeniz S 1995 Improvement of the fatigue-strength of AISI-4140 steel by an ion nitriding process. Surface \& Coatings Technology72 169-73

[13] Celik A and Karadeniz S 1996 Investigation of compound layer formed during ion nitriding of AISI 4140 steel Surface \& Coatings Technology80 283-6

[14] Alsaran A, Celik A and Celik C 2002 Determination of the optimum conditions for ion nitriding of AISI 5140 steel Surface \& Coatings Technology160 219-26

[15] Alsaran A, Karakan M and Celik A 2002 The investigation of mechanical properties of ion-nitrided AISI 5140 low-alloy steel Materials Characterization48 323-7

[16] Mohammadzadeh R, Akbari A and Drouet M 2014 Microstructure and wear properties of AISI M2 tool steel on RF plasma nitriding at different N2-H2 gas compositions Surface \& Coatings Technology258 566-73

[17] Ashara A H and Zou Q 2014 Tribological and metallurgical properties of nitrided AISI 4340 steel SAE International0959

[18] Muzart J L R, Binder R, Arroyo I K and Desouza A R 1993 Influence of temper temperature on plasma nitrided layer in AISI-4340 steel J. Mater. Sci. Lett.12 773-4

[19] Ribeiro K J B, de Sousa R R M, de Araujo F O, de Brito R A, Barbosa J C P and Alves C 2008 Industrial application of AISI 4340 steels treated in cathodic cage plasma nitriding technique Materials Science and Engineering: A479 142-7

[20] Sirin S Y and Kaluc E 2012 Structural surface characterization of ion nitrided AISI 4340 steel Materials \& Design36 741-7

[21] Yasavol N and Mahboubi F 2012 The effect of duplex plasma nitriding-oxidizing treatment on the corrosion resistance of AISI 4130 steel Materials \& Design38 59-63

[22] SoltaniAsadi Z and Mahboubi F 2012 Effect of component's geometry on the plasma nitriding behavior of AISI 4340 steel Materials and Design34 516-21

[23] Diaz-Guillen J C, Vargas-Gutierrez G, Granda-Gutierrez E E, Zamarripa-Pina J S, Perez-Aguilar S I, Candelas-Ramirez J and AlvarezContreras L 2013 Surface properties of Fe4N compounds layer on AISI 4340 steel modified by pulsed plasma nitriding Journal of Materials Science \& Technology29 287-90

[24] Arul Mozhi Varman J P, Uwe H and Balasubramanian M 2016 Effect of pulse repetition time on pulsed plasma nitriding of AISI 4340 steel Journal of Materials Science \& Surface Engineering4 (3) 386-91

[25] Zhong H, Dai L, Yue Y, Wang B, Zhang X, Tan C, Ma M and Liu R 2016 Tribological properties of plasma-nitrided AISI 4340 steel in vacuum Materials Science and Technology32 275-81

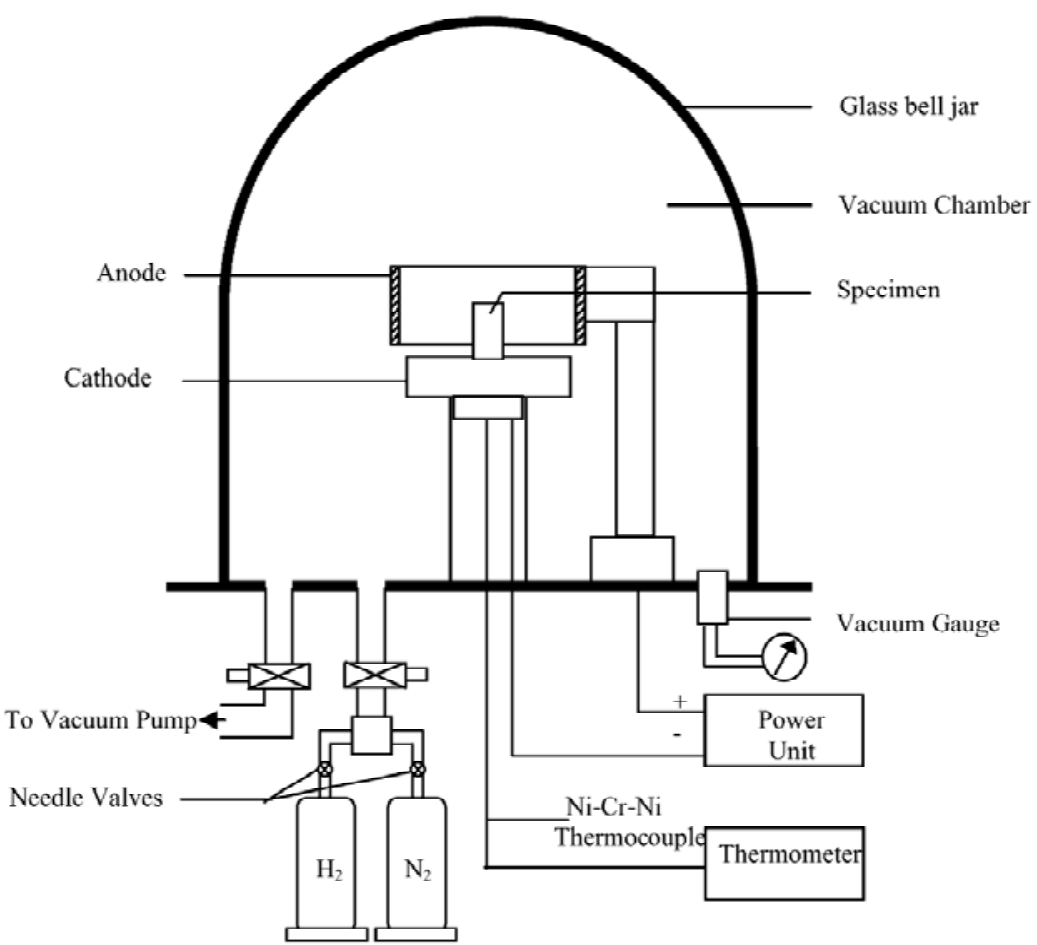

Figure 1. Schematic diagram of the ion nitriding system. 
ISSN (Print) : 2319-8613

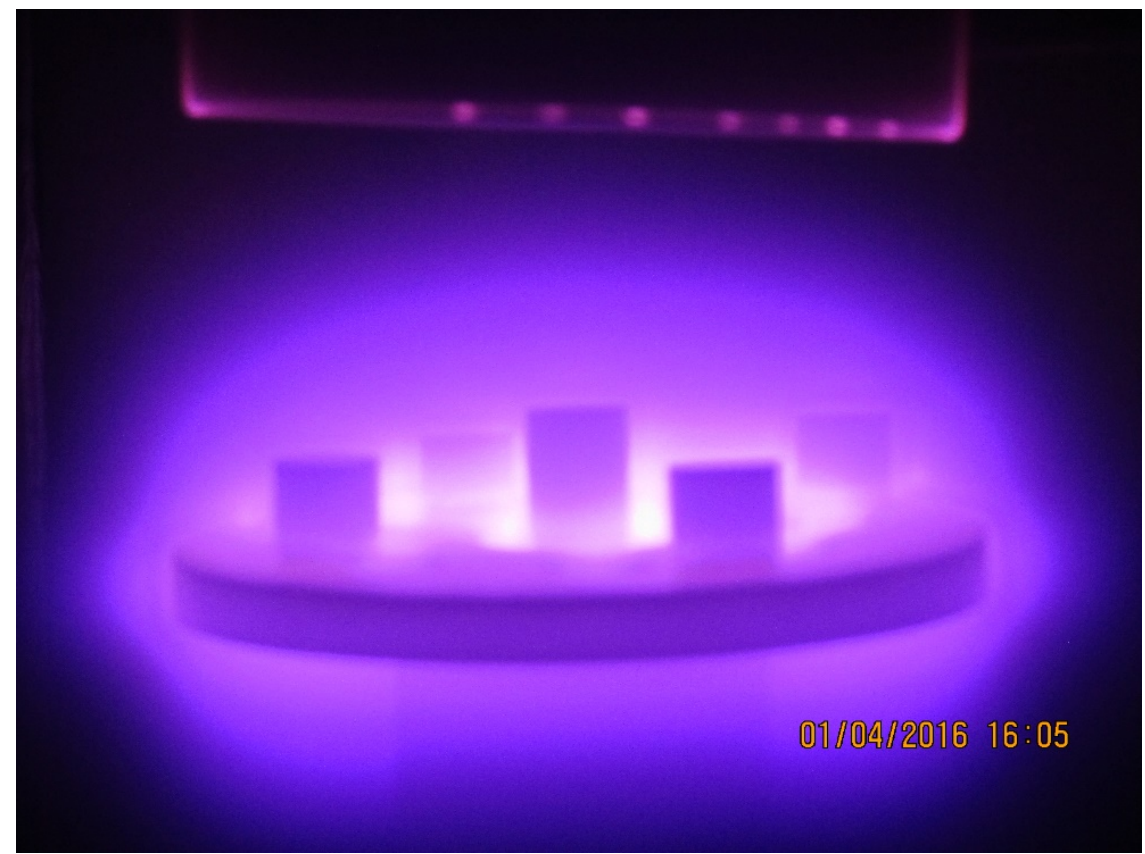

Figure 2. Plasma nitriding process

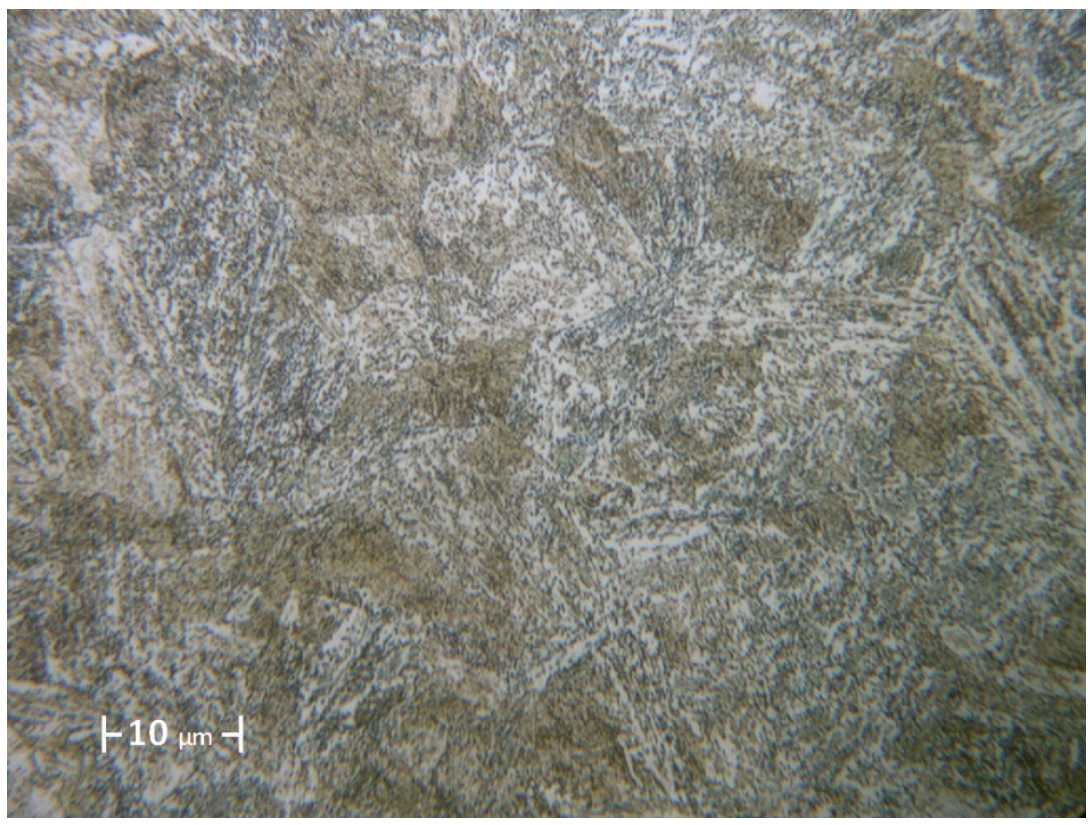

Figure 3. Typical optical microscopy images of the normalized sample 


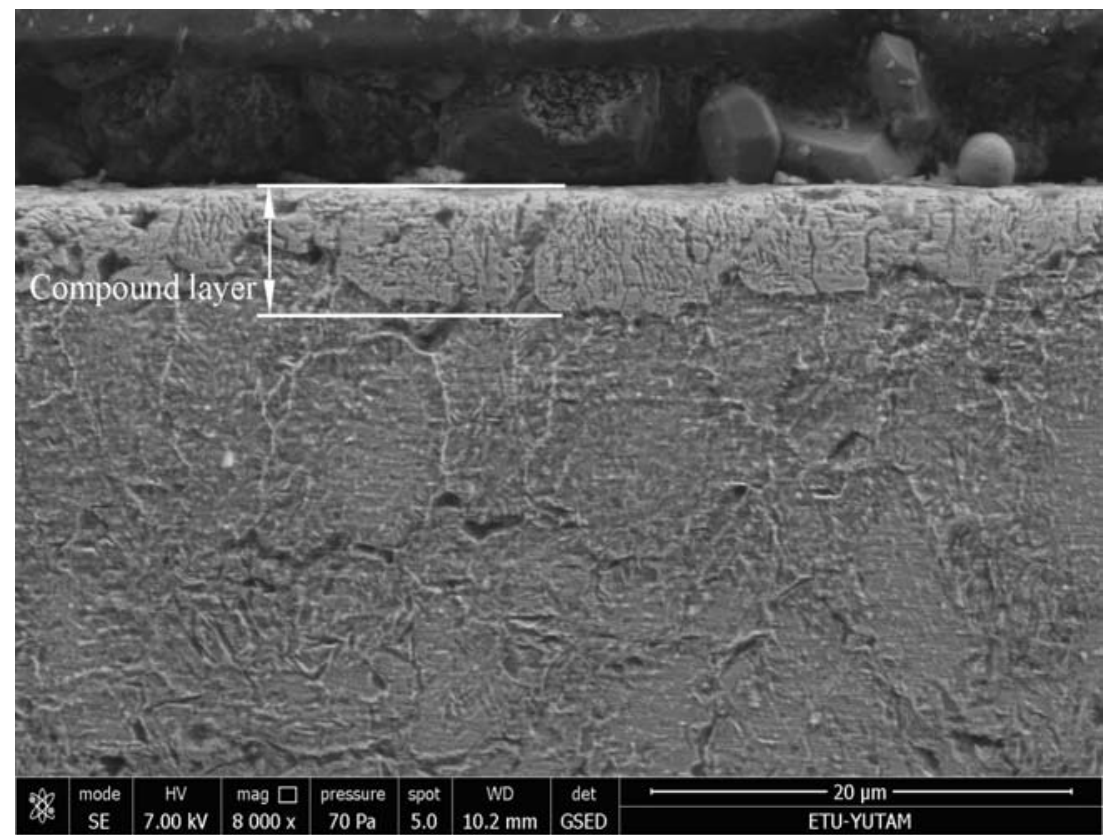

Figure 4. SEM micrographs of plasma nitrided AISI 4340 steel at $470^{\circ} \mathrm{C}, 8 \mathrm{~h}$

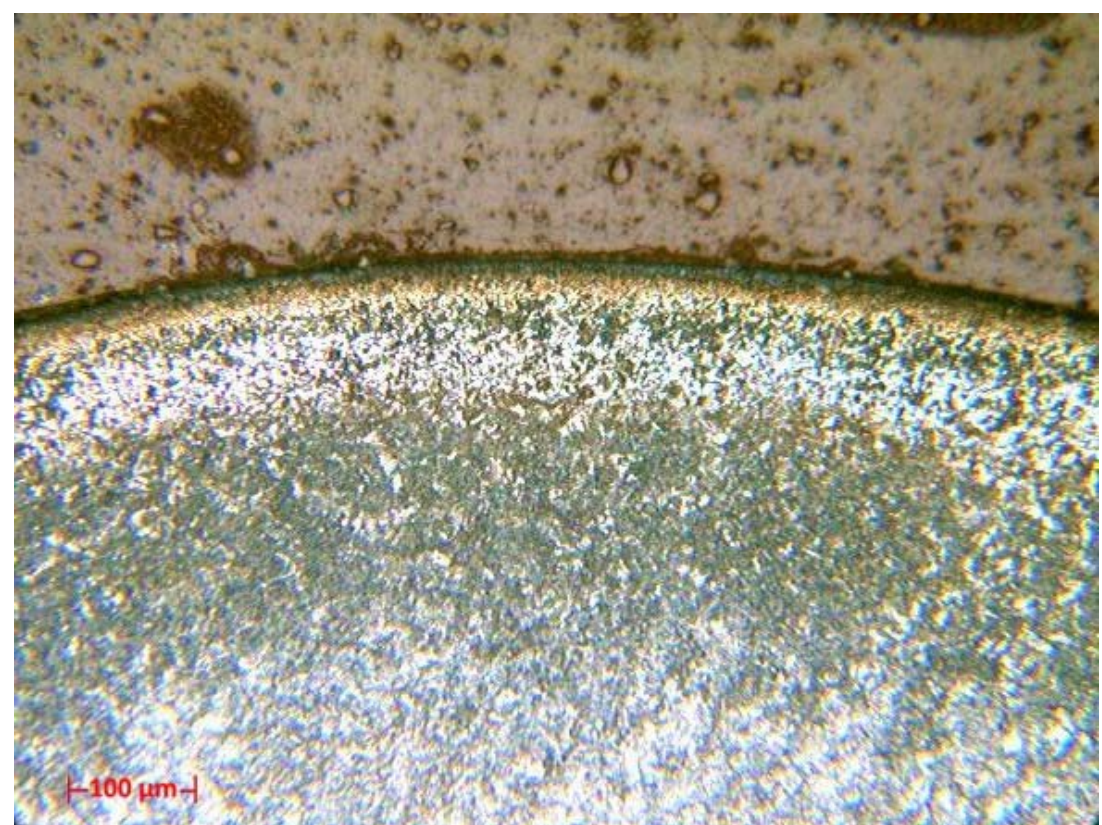

Figure 5. OM Micrographs of plasma nitrided AISI 4340 steel at $470^{\circ} \mathrm{C}, 8 \mathrm{~h}$ 


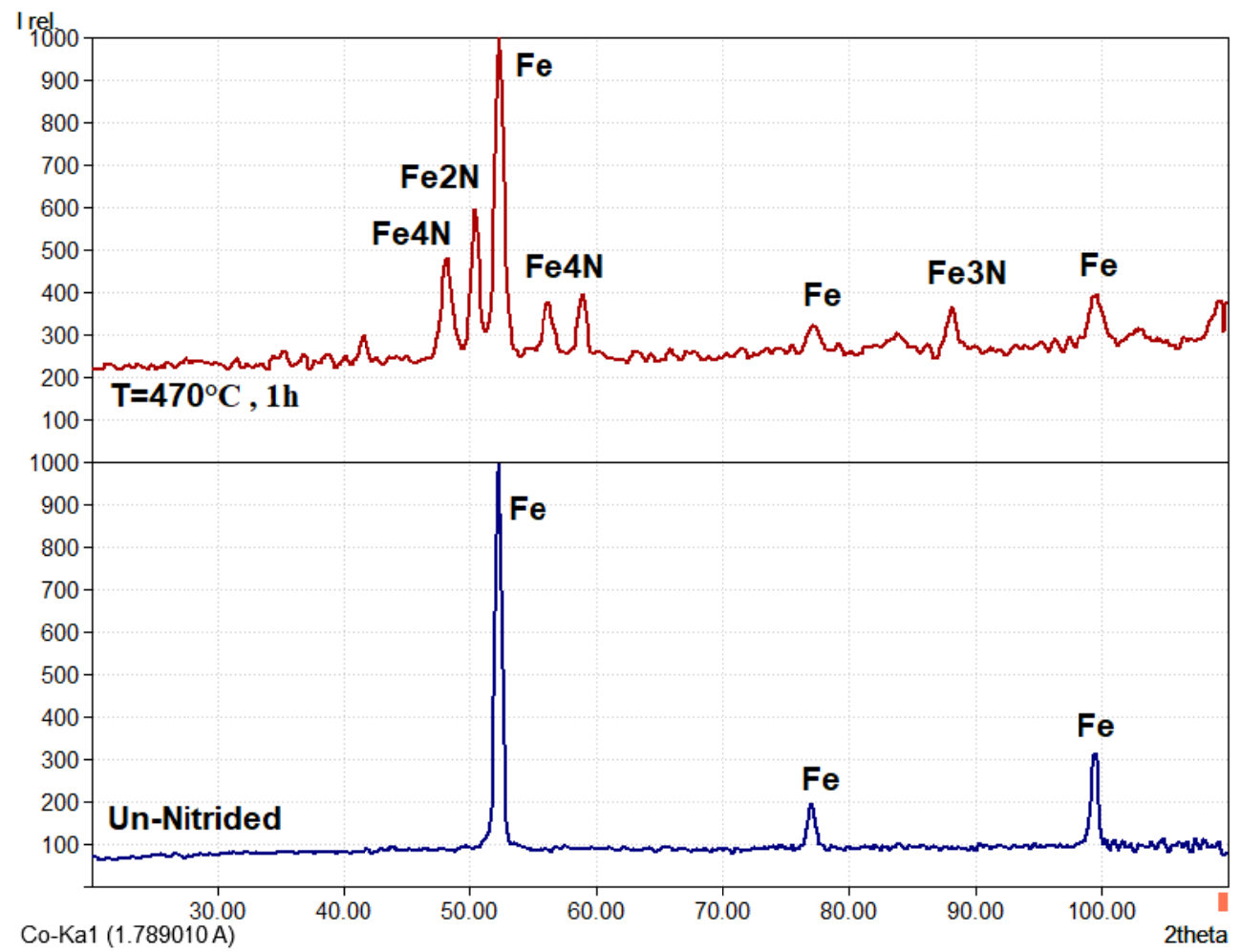

Figure 6. X-ray diffraction patterns of plasma nitrided AISI 4340 steel

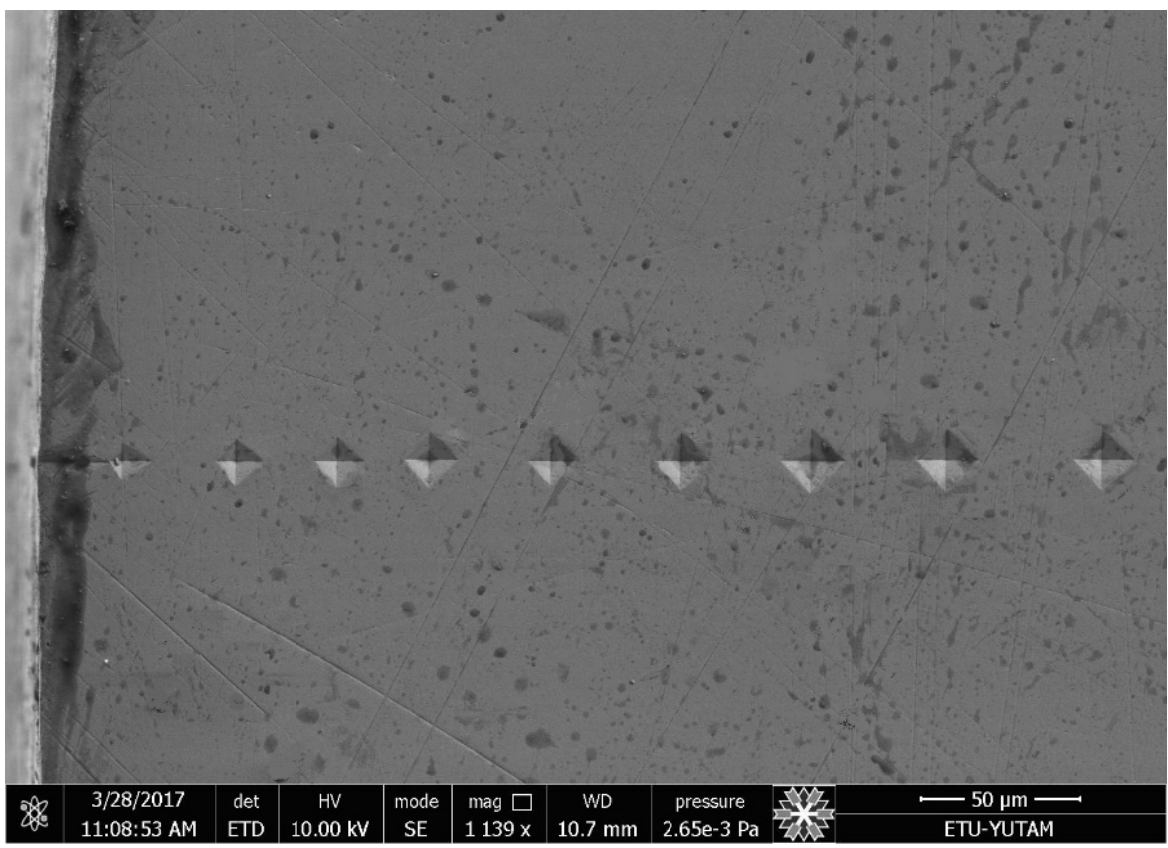

Figure 3. Micrograph of Vickers indents on plasma nitrided AISI 4340 steel at $470^{\circ} \mathrm{C}$ and $4 \mathrm{~h}$. 


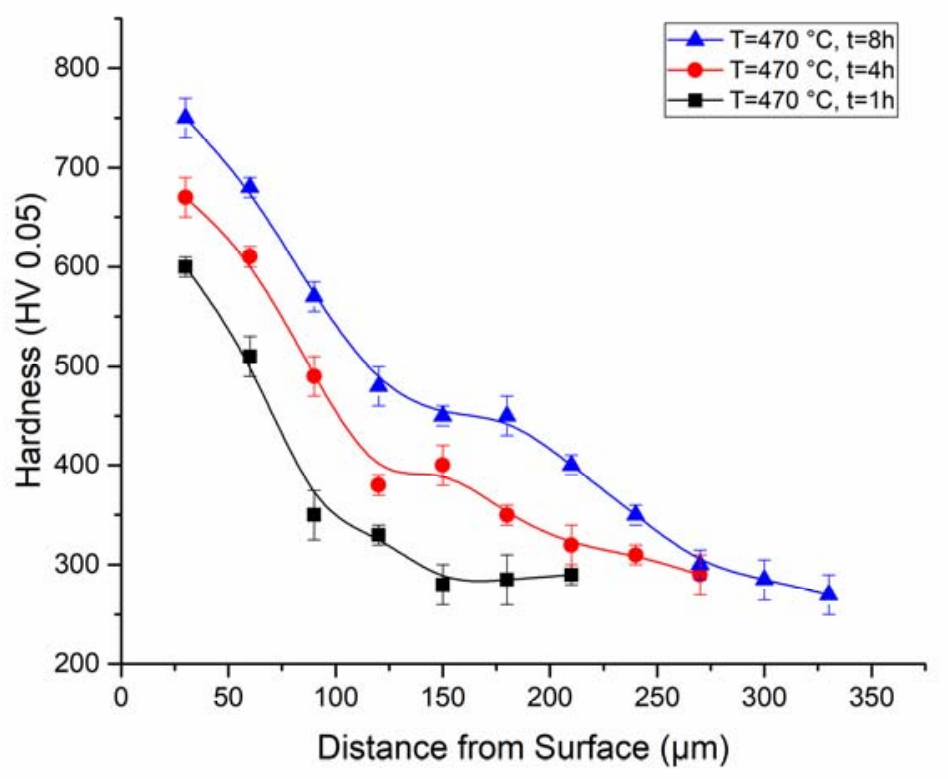

Figure 8. Microhardness profiles of AISI 4340 steel, plasma nitrided at different conditions. 